\title{
The additive effects of condensed tannins on the disappearances of protein, cell wall and lignin from semi-arid browse foliage in sacco
}

\author{
A. V. Goodchild ${ }^{1}$ and N. P. McMeniman' \\ 1 International Centre for Research in Dry Areas, PO Box 5466, Aleppo, Syria \\ ${ }^{2}$ University of Queensland, St Lucia, Australia
}

\section{Introduction}

Condensed tannin (proanthocyanidin or PCy) in the foliage of trees and shrubs (browse) can reduce the degradability of browse in the rumen, in particular its neutral-detergent (ND) fibre, fractions of ND fibre, and crude protein.

We have observed that over $90 \%$ of butanol- $\mathrm{HCl} \mathrm{PCy}$ in browse is soluble in ND with sulphite. We hypothesized that: (a) removing ND soluble matter from browse would improve the rumen degradability of ND fibre and its fractions in sacco (from nylon bags); (b) the improvement would be proportional to the PCy content of the browse; (c) ND soluble protein not degraded in the rumen would also vary with PCy content; and (d) the effects of PCy on the degradabilities of the various fractions would be correlated. These hypotheses were tested with the freeze-dried foliage of ten browse species collected from Charleville in subtropical semi-arid Queensland, Australia, in spring and autumn.

\section{Material and methods}

Seven rumen-cannulated Merino sheep were given $17 \mathrm{~g}$ dry matter (DM) per $\mathrm{kg}$ live weight per day of bird-resistant sorghum stover with urea and minerals for a 20-day period, the in sacco trial occupying the last 6 days. There were $2 \times 2 \times 2$ bags of each browse species, there being two types of preparation $(X$, extracted in ND or $W$, washed in warm water at 60 to $70^{\circ} \mathrm{C}$ ), two samples of browse, and two durations of incubation ( 48 or $96 \mathrm{~h}$ ). Six nylon bags were incubated in each sheep at once. The browse species were: MLG, mulga (Acacia aneura); IWD, ironwood ( $A$. excelsa); MYL, myall ( $A$. pendula); BEL, belalie (A. stenophylla); KRJ, kurrajong (Brachychiton populneum); BTT, bottle tree (B. rupestre); BMB, bumbil (Capparis mitchellii); LWD, leopardwood (Flindersia maculosa); WLG, wilga (Geijera parviflora); and RWD, rosewood (Heterodendron oleifolium), and were sampled in autumn and spring except for BEL, BMB and RWD (autumn only).
PCy was measured in a spectrophotometer at $550 \mathrm{~nm}$ after heating in $95: 5: 5: 5$ butan-1-ol: $\mathrm{HCl}$ : methanol : water at $95^{\circ} \mathrm{C}$ for $2 \mathrm{~h}$ (Bate-Smith, 1981), using mulga condensed tannin as a standard. For fibre analysis (Goering and Van Soest, 1970), sintered glass crucibles of porosity $2(0.020$ to $0.040 \mathrm{~mm})$ were used. Nylon bags had a pore size of $0.035 \mathrm{~mm}$, were $90 \times 170 \mathrm{~mm}$ internally and contained $2.2 \mathrm{~g} \mathrm{DM}$ of $W$ or an equivalent mass of $X$. All material was allowed to become equilibrated with air before sampling from nylon bags or crucibles. The residue of $W$ was then ND extracted for $2 h$, and $X$ was ND extracted for $1 \mathrm{~h}$, to make the total ND extraction times $2 \mathrm{~h}$ for both $W$ and $X$. Acid-detergent fibre and Klason lignin were determined on the ND residue, from which hemicellulose and cellulose were calculated.

\section{Results and discussion}

The yields of hot water-washed and ND-extracted browse DM are shown in Table 1. In all species proportionately over 0.9 of the PCy was soluble in ND and was therefore located mainly in cell contents. Of the nitrogen in the browse, most $(9$ to $19 \mathrm{mg} / \mathrm{g}$ browse DM, or $24 \mathrm{mg}$ in bumbil) was removed by ND; the residue of this fraction after rumen incubation is shown in Table 1 . The NDinsoluble nitrogen fraction was 5 to $7 \mathrm{mg} / \mathrm{g}$ browse DM in Acacia spp. or 2 to $4 \mathrm{mg}$ in others; about half of it was associated with lignin.

Between 0.16 and 0.27 of ND fibre disappeared from washed browse $(W)$ in 48 or $96 \mathrm{~h}$, with the exception of wilga (0.43). From browses that had previously been extracted in ND $(X)$, the disappearance of ND fibre ranged from two to three times higher than from $W$ (Brachychiton spp.), through 1.5 times higher (bumbil and rosewood), down to no significant difference (Acacia spp., leopardwood and wilga). Hemicellulose and cellulose were the main components of cell wall disappearing, but in wilga lignin alone was affected. 
Table 1 Composition of browose before incubation and residuc after incubation, and effects of prior ND-extraction on fibre residu's (mg/s original browusic dry imatter (DM))

\begin{tabular}{|c|c|c|c|c|c|c|c|c|c|c|c|}
\hline \multirow[b]{3}{*}{ Speciest } & \multicolumn{9}{|c|}{ Genus } & \multirow{3}{*}{\multicolumn{2}{|c|}{ RWD s.e. }} \\
\hline & \multicolumn{4}{|c|}{ Acacia } & \multicolumn{2}{|c|}{ Brachychiton } & \multicolumn{3}{|c|}{ Other } & & \\
\hline & MLG & IWD & MYL & BEL & KRJ & BTT & BMB & LWD & WLG & & \\
\hline \multicolumn{12}{|l|}{ Composition of original browse } \\
\hline Hot water-washed browse DM (W) & 803 & 787 & 716 & 596 & 851 & 817 & 640 & 809 & 670 & 747 & \\
\hline ND-extracted browse DM $(X)$ & 479 & 440 & 473 & 394 & 413 & 352 & 315 & 245 & 214 & 307 & \\
\hline Proanthocyanidin & 40 & 54 & 30 & 36 & 103 & 147 & 14 & 74 & 89 & 94 & \\
\hline \multicolumn{12}{|l|}{ Residue after incubation in the rument } \\
\hline ND-soluble $\mathrm{N} \times 6.25$ & 32 & 32 & 23 & 26 & 16 & 26 & $\mathbf{0}$ & 13 & 32 & 35 & $3 \cdot 2$ \\
\hline \multicolumn{12}{|l|}{$\begin{array}{l}\text { Difference in quantity of residue after } \\
\text { incubation between } W \text { and } X\end{array}$} \\
\hline Hemicellulose & 15 & 3 & 7 & 8 & $32^{*}$ & $53^{* * *}$ & 11 & 8 & 6 & $34^{*}$ & 10.8 \\
\hline Cellulose & 10 & 2 & 2 & 4 & $85^{* * *}$ & $39 * * *$ & 15 & 6 & 1 & $21^{*}$ & 9.4 \\
\hline Lignin & 0 & 1 & $\mathbf{0}$ & -7 & 6 & 16 & 14 & 19 & $24^{*}$ & 4 & $7 \cdot 3$ \\
\hline ND fibre & 24 & 5 & 6 & -3 & $101^{* * *}$ & $112^{* * *}$ & $38^{*}$ & 25 & 29 & $48^{*}$ & $15 \cdot 6$ \\
\hline
\end{tabular}

+ See Material and methods

$\ddagger 0.27$ of ND soluble $N \times 6.25$ was not degraded in bumbil; this fraction was subtracted from the undergraded ND-soluble $N$ $\times 6.25$ of all browses.

Three possible effects of PCy were studied: E1, undegraded ND-soluble $N \times 6.25 ; E 2$, increase in undegraded cellulose and hemicellulose; $E 3$, increase in undegraded lignin. The correlations $(r)$ of these $E$ values with $P C y$ concentration were $-0.09,0.79$ $(P<0.05)$ and 0.65 , respectively. Within PCy levels, the correlations between the $E$ values were negative: $-0.23(E 1, E 2),-0.18(E 1, E 3)$ and $-0.73(P<0.05)(E 2$, $E 3)$, indicating that the effects of PCy were mutually exclusive. Klason lignin residues were associated with cell wall disappearance, consistent with the hypothesis that the extra 'lignin' was inactivated tannin (Goodchild and McMeniman, 1992). By multiple regression, the combined effects of $E 1, E 2$ and $E 3$ were highly correlated with PCy:

$$
\begin{gathered}
\mathrm{PCy}(\mathrm{mg} / \mathrm{g})=17.1+0.85 E 1(P>0.05) \\
+0.73 E 2(P<0.01)+2.07 E 3(P<0.01) \\
(r=0.952 ; P<0.001) .
\end{gathered}
$$

There are several possible reasons for betweenspecies differences in the effect of tannin on components such as ND soluble nitrogen, (hemi) cellulose and lignin. These include species variation in: (a) chemistry or microstructural interrelationships of components; (b) specificity of tannins, either for components or for rumen microbes and their enzymes; (c) localization of tannins in plant tissues. Since favourable effects of condensed tannins on ruminant nutrition are known, future work should optimize the relationship between tannins, nutritional components, plant tissues and rumen microbes.

\section{References}

Bate-Smith, E. C. 1981. Astringent tannins of the leaves of Geranium species. Phytochemistry 20: 211-216.

Goering, H. K. and Van Soest, P. J. 1970. Forage fiber analysis. US Department of Agriculturc. Agricultural Handbook No. 379.

Goodchild, A. V. and McMeniman, N. P. 1992. Disappearance of sorghum stover polyphenols and browse condensed tannins in the sheep gut. In Animal production in developing countries (ed. M. Gill, E. Owen, G. E. Pollott and T. L. J. Lawrence), pp. 196-197. Occasional publication, British Society of Animal Production, no. 16. 